\title{
PERAN PONDOK PESANTREN DALAM PEMBENTUKAN KARAKTER SANTRI
}

\author{
Ria Gumilang1, Asep Nurcholis ${ }^{2}$ \\ 123 IKIP SILIWANGI \\ ${ }^{1}$ ria.gumilang.rg@gmail.com
}

\begin{abstract}
ABSTRAK
Penelitian ini dilatarbelakangi oleh fenomena yang terjadi di masyarakat yaitu (1) generasi muda yang memiliki karakter yang kurang baik dalam hal budi pekerti, (2) kurang optimalnya lembaga pendidikan dalam menanamkan nilai-nilai, cita-cita dan motivasi yang akan mendorong generasi muda memiliki kepribadian yang baik, (3) Kurangnya pengetahuan orang tua mengenai cara membentuk karakter anak agar memiliki kepribadian yang baik dalam hal budi pekerti. Pondok Pesantren Al Firdaus memiliki kurikulum yang lebih mengutamakan pendidikan karakter dalam proses pembelajarannya. Metode penelitian yang digunakan adalah metode deskriptif dengan pendekatan kualitatif untuk lebih menggali inti dari permasalahan penelitian dengan teknik pengumpulan data menggunakan wawancara pada pengelola, pengajara dan santri sebagai objek pendidikan. Teori yang menjadi rujukan dalam penelitian ini diantaranya teori pendidikan karakter, Teori pengelolaan lembaga pendidikan pondok pesantren, dan konsep pendidikan luar sekolah. Hasil penelitian adalah (1) Dari 50 santri, 51\% santri memiliki kejujuran yang sangat baik, 52\% memiliki tingkat kedisiplinan yang sangat tinggi, $48 \%$ santri yang memperhatikan kebersihan dengan sangat baik, 18\% kepedulian santri, kemandirian 32\%, santri yang memiliki kemandirian dan kerja keras hanya $38 \%$, kesopanan 40\%, tanggung jawab 28\%, dan kreativitas 62\%. (2) Upaya pondok pesantren yaitu mengelola pembelajaran dengan materi karakter $60 \%$ melalui pembiasaan aktivitas sehari-hari dan $40 \%$ penguasaan materi keagamaan dan umum. (3) Faktor penghambat dalam proses pendidikan karakter diantaranya adalah pola asuh orang tua dirumah dan pola pendidikan di pondok pesantren masih belum sinkron sehingga perlu penyamaan persepsi antara orang tua dan pengajar di pondok pesantren.
\end{abstract}

Kata Kunci : Karakter Santri, Pendidikan Karakter, Pondok Pesantren.

\section{PENDAHULUAN}

Saat ini bangsa kita sedang dirundung berbagai masalah dalam menghadapi realitas kehidupan dan zaman. Masyarakat Indonesia yang menjunjung nilai-nilai Pancasila khususnya sila ke-dua "Kemanusiaan yang adil dan beradab", namun makna adab masih mengalami kekaburan dan pembiasan dalam masyarakat, ada yang menganggap hanya sebagai bentuk dari nilai-nilai moral, kesopanan, dan budipekerti.

Pemahaman tetntang pendidian karakter masih sangat rendah diIndonesia. Hal ini dapat ditunjukan dengan terjadinya banyak permasalahan di setiap hari dan hampir 
pada setiap lini kehidupan masyarakat. Mulai dari perorangan, dalam keluarga hingga lingkungan masyarakat. Lebih menyedihkan bila terjadi di bidang pendidikan.

Maraknya kasus bullying di sekolah, murid yang kurang menghormati guru dan kasuskasus lain yang berkaitan dengan kemerosotan adab. Pada dasarnya setiap insan mendambakan akhlak yang mulia, sehingga menjadikan masyarakat yang berakhlak mualia dan beradab. Namun, perlu disadari karakter yang baik tidak akan tumbuh sendiri. Kemerosotan adab saat ini meresahkan di segala lini masyarakat. Sungguh memerlukan lingkungan subur yang kondusif sengaja diciptakan untuk itu, yang memungkinkan potensi dapat tumbuh optimal, dengan generasi berakhlakul karimah. Mempunyai seorang anak merupakan anugrah yang diberikan Allah SWT kepada kita yang wajib disyukuri, karena anak merupkan penerus keturunan kita baik di lingkungan keluarga juga masyarakat luas. Maka sudah menjadi kewajiban orangtua atau orang disekelilingnya untuk memberikan perhatian dalam masalah agama yang meliputi keimanan, ibadah dan akhlak. Karena agama adalah pedoman manusia hidup manusia di dunia dan akhirat, juga sangat mempengaruhi seleruh aspek kehidupan manusia baik secara lahir juga batin. Oleh sebab itu faktor lingkungan kondusif yang berpengaruh terhadap perkembangan anak sebagai generasi penerus.

\section{KAJIAN PUSTAKA}

\section{A. Konsep Pondok Pesantren}

\section{Pengertian Pondok Pesantren}

Pesantren Secara etimologis Pengertian Pondok Pesantren adalah, "pesantren" berasal dari pe-santri-an yang berarti tempat santri; asrama tempat santri belajar agama; atau pondok. Dikatakan pula, pesantren berawal dari kata santri, yaitu seorang yang mempelajari agama Islam, maka dari itu pesantren mempunyai arti tempat orang-orang berkumpul untuk belajar agama Islam. (Dhofier, 1983), Pondok pesantren berasal dari dua kata, yaitu pondok dan pesantren.

Pondok berasal dari bahasa Arab "Funduq" yang mempunyai tempat menginap, atau asrama. Sedangkan pesantren berasal dari bahasa Tamil, dari kata santri, diimbuhi ditambah awalan pe dan akhiran -an yang berarti para penuntut ilmu. (Ali \& Daud, 1995). Pondok Pesantren merupakan lembaga pendidikan Islam tertua di Indonesia.

Lembaga pondok pesantren berperan penting dalam usaha meningkatkan pendidikan bagi bangsa Indonesia terutama pendidikan agama Islam. Adanya pondok pesantren di tengah-tengah masyarakat Indonesia tidak hanya sebagai lembaga pendidikan, tetapi juga sebagai lembaga penyiaran agama dan sosial keagamaan. Melakukan kegiatan dakwah di kalangan masyarakat, dalam arti kata melakukan aktivitas menumbuhkan kesadaran beragama untuk melaksanakan ajaran-ajaran Islam secara konsekuen sebagai pemeluk agama Islam.

Sebagai Lembaga sosial pesantren ikut terlibat dalam menangani masalah-masalah sosial yang dihadapi masyarakat. Dalam perkembangannya pondok pesantren mengalami perubahan sesuai dengan situasi dan kondisi bangsa Indonesia. (Zulhimma, 2013) Secara terminologis, pesantren merupakan institusi sosial keagamaan yang menjadi wahana pendidikan bagi umat Islam yang ingin mendalami ilmu-ilmu keagamaan. 
Pondok pesantren dalam terminologi Islam sebagai institusi pendidikan Islam, namun demikian pesantren memiliki ciri khas sosial yang memiliki pranata sosial di masyarakat. Hal ini karena pondok pesantren memiliki dasar kepekaan sosial yang khas, yaitu: 1) ketokohan kyai, 2) santri, 3) independent dan mandiri, dan 4) jaringan sosial yang kuat antar alumni pondok pesantren(Maksum, 2015) .

\section{Fungsi Pesantren}

Fungsi pesantren tidak semata-mata hanya sebagai lembaga pendidikan tafaqquh fi aldien an sich, tetapi multi komplek yang menjadi tugas pesantren. Aktivitas belajar mengajar di pesantren tidak hanya memberikan ilmu saja. Azyumardi Azra menyebutkan, selain memberikan ilmu, pesantren juga sebagai peremajaan ulama' dan sebagai pelestari budaya Islam.

Dua unsur tambahan tersebut perlu ditekankan sebab seorang ulama' bukan hanya orang yang mempunyai penguasaan ilmu yang tinggi, tetapi juga harus disertai dengan kemampuan mengamalkan ilmu tersebut.Hal senada juga dikemukakan oleh Tholkhah Hasan mantan menteri agama RI, bahwa pesantren seharusnya mampu menghidupkan fungsi-fungsi sebagai berikut, 1) pesantren sebagai lembaga pendidikan yang melakukan pembekalan ilmu-ilmu agama (tafaqquh fi al-din) dan nilai- nilai Islam (Islamic values); 2) pesantren sebagai lembaga keagamaan yang melakukan kontrol sosial; dan 3) pesantren sebagai lembaga keagamaan yang melakukan rekayasa sosial (social engineering) atau perkembangan masyarakat (community development).

Semua itu, menurutnya hanya bisa dilakukan jika pesantren mampu melakukan proses pelestarian tradisi- tradisi yang baik dan sekaligus mengadaptasi perkembangan keilmuan baru yang lebih baik, sehingga mampu memainkan peranan sebagai agent of change. (Syafe'i, 2017). Oleh karena itu pondok pesantren bukan hanya pada transfer pengetahuan saja namun pada pembentukan karakter.

\section{Jenis Pesantren}

Menurut para ahli pendidikan, pengklasifikasi jenis pesantren ke dalam dua tipologi; yakni pesantren modern, yang sudah banyak menerapkan sistem pendidikan sekolah modern Barat dan pesantren salaf, yang berorientasi pada pelestarian tradisi dengan sistem pendidikan tradisional. (Maksum, 2015) Pertama, pesantren Salaf. Menurut Zamakhsyari Dhofier, ada beberapa ciri pesantren salaf atau tradisional, terutama dalam hal sistem pengajaran dan materi yang diajarkan.

Pengajaran kitab- kitab Islam klasik atau sering disebut dengan kitab kuning karena kertasnya berwarna kuning, terutama karangan-karangan ulama yang menganut faham Syafi'iyah, merupakan pengajaran formal yang diterapkan dalam lingkungan pesantren tradisional. Keseluruhan kitab-kitab klasik yang diajarkan di pesantren dapat digolongkan ke dalam delapan kelompok, yaitu nahwu (syntax) dan shorof (morfologi), fiqh, usul fiqh, hadis, tafsir, tauhid, tasawuf dan etika, dan cabang-cabang lain seperti tarikh dan balaghah.

(Dhofier, 1983) Pondok pesantren sebagai lembaga pendidikan tertua di Indonesia memang senantiasa melestarikan nilai-nilai pendidikan berbasis pengajaran tradisional. 
Pelestarian akan sistem dan metodologi tradisional itulah yang lantas menjadikan pesantren semodel ini disebut sebagai pesantren tradisional. Pelestarian nilai-nilai tersebut dapat dengan mudah dilacak dalam kehidupan santri yang sehari-harinya hidup dalam kesederhanaan, belajar tanpa pamrih dan penuh tanggung jawab, serta terikat oleh rasa solidaritas yang tinggi (Geertz, 1981).

\section{B. Konsep Pendidikan Karakter}

1. Pengertian Pendidikan Karakter

Istilah ini merupakan ekspresi kepribadian santri hasil dari tempaan pesantren tradisional yang juga sebagai pondasi awal santri untuk sosialisasi dengan masyarakatnya kelak. Kiai dalam tipologi ini merupakan figur sentral yang sikap sehariharinya banyak mempengaruhi kepribadian santri. Karena itu, banyak orang yang beranggapan bahwa pendidikan di pondok pesantren tradisional seolah tidak mengenal libur, pembelajaran serta pengamalan ilmu berlaku siang dan malam dalam sepanjang tahun (Muhakamurrohman, 2014) Kedua, Pondok pesantren modern, merupakan pengembangan tipe pesantren karena orientasi belajarnya cenderung menerapkan seluruh sistem pembelajaran secara klasik dan meninggalkan sistem belajar tradisional.

Penerapan sistem pembelajaran modern ini terutama nampak pada penggunaan kelaskelas belajar baik dalam bentuk madrasah maupun sekolah. Kurikulum yang digunakan adalah kurikulum sekolah atau madrasah yang berlaku secara nasional. Santrinya ada yang menetap ada yang tersebar di sekitar desa lokasi pesantren. Kedudukan para kyai sebagai koordinator pelaksana proses belajar mengajar dan sebagai pengajar langsung di kelas.

Perbedaannya dengan sekolah dan madrasah adalah pada porsi pendidikan agama dan bahasa Arab lebih menonjol sebagai kurikulum wajib. (Maksum, 2015) Dari fisik, infrastruktur, dan sistem pendidikan, pesantren modern dapat dengan mudah dibedakan dari pesantren salafi atau pesantren tradisional. Bangunan-bangunan pesantren modern lebih bersih dan terawat, adanya dapur-dapur siap saji, adanya pakaian seragam, auditorium megah, lapangan olahraga, ruang pengembangan bakat dan keterampilan, hingga laboratorium bahasa.

Karakter diibaratkan mengukir diatas batu permata. Selanjutnya berkembang pengertian karakter yang diartikan sebagai tanda khusus atau pola perilaku. (Bohlin, Deborah, \& Kevin, 2001) Pendidikan Karakter menjadi sesuatu yang hangat diperbincangkan saat ini karena ditemukannya berbagai kasus penyimpangan yang menunjukkan rendahnya karakter generasi saat ini. Hasil survei memperoleh temu- an sebagai berikut (1) setiap hari sekitar 160.000 siswa mendapatkan tindakan bullying di sekolah, 1 dari 3 usia respon- den yang diteliti (siswa pada usia 18 tahun) pernah mendapat tindakan ke- kerasan, 75-80\% siswa pernah meng- amati tindak kekerasan, 15-35\% siswa adalah korban kekerasan dari tindak kekerasan maya (cyber-bullying). (Mazzola, 2013) Istilah karakter dihubungkan dengan istilah etika, ahlak, dan atau nilai dan berkaitan dengan kekuatan moral, berkonotasi "positif" bukan netral. (Kemendiknas, 2010). Oleh karena itu Pendidikan karakter secara lebih luas dapat diartikan sebagai pendidikan yang mengembangkan nilai budaya dan karakter bangsa pada diri peserta didik sehingga mereka memiliki nilai dan karakter sebagai karakter 
dirinya, menerapkan nilai-nilai tersebut dalam kehidupan dirinya sebagai anggota masyarakat, dan warga negara yang religius, nasionalis, produktif, dan kreatif(Ainiyah, 2013) Konfigurasi karakter sebagai sebuah totalitas proses psikologis dan sosialkultural dapat dikelompokan dalam: Olah Hati (Spiritual and emotional development), Olah Pikir (intellectual development), Olah Raga dan Kinestetik (Physical and kinestetic development), dan Olah Rasa dan Karsa (Affective and Creativity development). Keempat proses psikososial (olah hati, olah pikir, olah raga, dan olahrasa dan karsa) yang erat kaitannya dan saling melengkapi, yang fokus pada pembentukan karakter yang menjunjung perwujudan dari nilai-nilai luhur. (Kemendiknas, 2010). Pendidikan karakter menjadi tugas bersama para pelaku pendidikan baik formal juga non formal.

\section{METODE PENELITIAN}

Metode penelitian yang digunakan adalah metode deskriptif dengan pendekatan kualitatif. Teknik pengumpulan data melalui wawancara, dan observasi pada pengelola, pengajara, dan santri. Jumlah sampel penelitian yaitu 50 santri usia 13-15 atau santri remaja setara SMP.

\section{HASIL DAN PEMBAHASAN}

\section{A. Hasil}

Penelitian ini bertujuan untuk mengetahui gambaran awal karakter santri Al- Firdaus, mengetahui peranan dan kecermatan santri dalam kegiatan belajar melalui penerapan pembelajaran Agama Islam di Pesantren Al-Firdaus, serta memberi masukan untuk lembaga/instansi yang ada kaitannya dengan hasil penelitian tersebut. Berdasarkan tujuan dan langkah-langkah pengolahan data, hasil penelitian digambarkan sebagai berikut:

\section{Gambaran Kondisi Awal Karakter Santri di Pondok Pesantrn Al-Firdaus}

Setelah melakukan pengamatan dan observasi terhadap santri Pondok Pesantren AlFirdaus, gambaran kondisi awal karakter santri di Pesantren Al-Firdaus sebelum pendidik menggunakan metode pembelajaran Agama Islam, di lihat secara garis besar sebagian besar santri sudah memperlihatkan mempunyai karakter positif, seperti santun dalam perilaku, peduli juga mandiri.

Berdasarkan hasil pengumpulan data menggunakan kuesioner tertutup terhadap 50 santri Pondok Pesantren Al-Firdaus diperoleh data sebagai berikut:

a. Kejujuran

Tabel 1

Tingkat kejujuran berkata

\begin{tabular}{cccc}
\hline NO & ASPEK & JUMLAH & PERSENTASE \\
\hline $\mathbf{1}$ & SELALU & 23 & $46 \%$ \\
$\mathbf{2}$ & SERING & 6 & $12 \%$ \\
$\mathbf{3}$ & KADANG & 21 & $42 \%$ \\
$\mathbf{4}$ & PERNAH & 0 & $0 \%$ \\
$\mathbf{5}$ & TIDAK PERNAH & 0 & $0 \%$ \\
$\quad$ & TOTAL & 50 & $100 \%$ \\
\hline
\end{tabular}


Berdasarkan data diatas dapat disimpulkan bahwa santri Pondok Pesantren Al-Firdaus tergolong memiliki tingkat kejujuran yang tinggi terbukti sebesar $46 \%$ sering berkata jujur dan tidak pernah ada yang tidak jujur.

Tabel 2

Tingkat kejujuran dalam mengembalikan barang pada pemiliknya

\begin{tabular}{cccc}
\hline NO & ASPEK & JUMLAH & PERSENTASE \\
\hline $\mathbf{1}$ & SELALU & 28 & $56 \%$ \\
$\mathbf{2}$ & SERING & 18 & $36 \%$ \\
$\mathbf{3}$ & KADANG & 4 & $8 \%$ \\
$\mathbf{4}$ & PERNAH & 0 & $0 \%$ \\
$\mathbf{5}$ & TIDAK PERNAH & 0 & $0 \%$ \\
$\quad$ TOTAL & 50 & $100 \%$ \\
\hline
\end{tabular}

Berdasarkan data diatas dapat disimpulkan bahwa santri Pondok Pesantren Al-Firdaus tergolong memiliki tingkat kejujuran yang tinggi terbukti sebesar 56\% selalu mengembalikan barang pada pemiliknya.

b. Kedisiplinan

Tabel 3

Tingkat ketaatan dalam shalat tepat waktu

\begin{tabular}{cccc}
\hline NO & ASPEK & JUMLAH & PERSENTASE \\
\hline $\mathbf{1}$ & SELALU & 32 & $64 \%$ \\
$\mathbf{2}$ & SERING & 15 & $30 \%$ \\
$\mathbf{3}$ & KADANG & 3 & $6 \%$ \\
$\mathbf{4}$ & PERNAH & 0 & $0 \%$ \\
$\mathbf{5}$ & TIDAK PERNAH & 0 & $0 \%$ \\
$\quad$ TOTAL & 50 & $100 \%$ \\
\hline
\end{tabular}

Berdasarkan data diatas dapat disimpulkan bahwa santri Pondok Pesantren Al-Firdaus tergolong memiliki tingkat kedisiplinan yang tinggi terbukti sebesar $64 \%$ selalu solat tepat waktu.

Tabel 4

Tingkat kedisliplinan datang tepat waktu

\begin{tabular}{cccc}
\hline NO & ASPEK & JUMLAH & PERSENTASE \\
\hline $\mathbf{1}$ & SELALU & 25 & $50 \%$ \\
$\mathbf{2}$ & SERING & 10 & $20 \%$ \\
$\mathbf{3}$ & KADANG & 14 & $28 \%$ \\
$\mathbf{4}$ & PERNAH & 0 & $0 \%$ \\
$\mathbf{5}$ & TIDAK PERNAH & 1 & $2 \%$ \\
\hline & TOTAL & 50 & $100 \%$ \\
\hline
\end{tabular}


Berdasarkan data diatas dapat disimpulkan bahwa santri Pondok Pesantren Al-Firdaus tergolong memiliki tingkat kedisiplinan yang tinggi terbukti sebesar 50\% sering datang tepat waktu.

c. Kebersihan

Tabel 5

Tingkat kebersihan membuang sampah pada tempatnya

\begin{tabular}{cccc}
\hline NO & ASPEK & JUMLAH & PERSENTASE \\
\hline $\mathbf{1}$ & SELALU & 24 & $48 \%$ \\
$\mathbf{2}$ & SERING & 17 & $34 \%$ \\
$\mathbf{3}$ & KADANG & 9 & $18 \%$ \\
$\mathbf{4}$ & PERNAH & 0 & $0 \%$ \\
$\mathbf{5}$ & TIDAK PERNAH & 0 & $0 \%$ \\
& TOTAL & 50 & $100 \%$ \\
\hline
\end{tabular}

Berdasarkan data diatas dapat disimpulkan bahwa santri Pondok Pesantren Al-Firdaus tergolong memiliki tingkat kebersihan yang tinggi terbukti sebesar $48 \%$ selalu membuang sampah pada tempatnya.

Tabel 6

Tingkat kepedulian memperhatikan teman yang sakit

\begin{tabular}{cccc}
\hline NO & ASPEK & JUMLAH & PERSENTASE \\
\hline $\mathbf{1}$ & SELALU & 9 & $18 \%$ \\
$\mathbf{2}$ & SERING & 9 & $18 \%$ \\
$\mathbf{3}$ & KADANG & 26 & $52 \%$ \\
$\mathbf{4}$ & PERNAH & 6 & $12 \%$ \\
$\mathbf{5}$ & TIDAK PERNAH & 0 & $0 \%$ \\
& TOTAL & 50 & $100 \%$ \\
\hline
\end{tabular}

Berdasarkan data diatas dapat disimpulkan bahwa santri Pondok Pesantren Al-Firdaus tergolong memiliki tingkat kepedulian sedang terbukti sebesar 52\% kadang memperhatikan teman yang sakit.

d. Kemandirian

Tabel 7

Tingkat kemandirian mengerjakan tugas pribadi sendiri

\begin{tabular}{cccc}
\hline NO & ASPEK & JUMLAH & PERSENTASE \\
\hline $\mathbf{1}$ & SELALU & 16 & $32 \%$ \\
$\mathbf{2}$ & SERING & 19 & $38 \%$ \\
$\mathbf{3}$ & KADANG & 15 & $30 \%$ \\
$\mathbf{4}$ & PERNAH & 0 & $0 \%$ \\
$\mathbf{5}$ & TIDAK PERNAH & 0 & $0 \%$ \\
& TOTAL & 50 & $100 \%$ \\
\hline
\end{tabular}


Berdasarkan data diatas dapat disimpulkan bahwa santri Pondok Pesantren Al-Firdaus tergolong memiliki kemandirian yang baik terbukti 38\% sering melakukan tugas sendiri, dan $0 \%$ untuk yang pernah dan tidak pernah.

e. Kerja keras

Tabel 8

Tingkat kerajin belajar

\begin{tabular}{cccc}
\hline NO & ASPEK & JUMLAH & PERSENTASE \\
\hline $\mathbf{1}$ & SELALU & 7 & $14 \%$ \\
$\mathbf{2}$ & SERING & 17 & $34 \%$ \\
$\mathbf{3}$ & KADANG & 24 & $48 \%$ \\
$\mathbf{4}$ & PERNAH & 2 & $4 \%$ \\
$\mathbf{5}$ & TIDAK PERNAH & 0 & $0 \%$ \\
\hline & TOTAL & 50 & $100 \%$ \\
\hline
\end{tabular}

Berdasarkan data diatas dapat disimpulkan bahwa santri Pondok Pesantren Al-Firdaus tergolong memiliki tingat kerajinan belajar 34\% sering melakukan tugas sendiri, dan $0 \%$ untuk yang pernah dan tidak pernah.

Tabel 9

Tingkat kerja keras meyetor hafalan sesuai target

\begin{tabular}{cccc}
\hline NO & ASPEK & JUMLAH & PERSENTASE \\
\hline $\mathbf{1}$ & SELALU & 32 & $64 \%$ \\
$\mathbf{2}$ & SERING & 8 & $16 \%$ \\
$\mathbf{3}$ & KADANG & 10 & $20 \%$ \\
$\mathbf{4}$ & PERNAH & 0 & $0 \%$ \\
$\mathbf{5}$ & TIDAK PERNAH & 0 & $0 \%$ \\
& TOTAL & 50 & $100 \%$ \\
\hline
\end{tabular}

Berdasarkan data diatas dapat disimpulkan bahwa santri Pondok Pesantren Al-Firdaus tergolong memiliki tingkat kerja keras dalam menyetor hafalan yang baik terbukti $64 \%$ selalu melakukan tugas sendiri, dan $0 \%$ untuk yang pernah dan tidak pernah.

f. Kesopanan dan Toleransi

Tabel 10

Tingkat kesopanan terhadap orang tua

\begin{tabular}{cccc}
\hline NO & ASPEK & JUMLAH & PERSENTASE \\
\hline $\mathbf{1}$ & SELALU & 28 & $56 \%$ \\
\hline $\mathbf{2}$ & SERING & 18 & $36 \%$ \\
$\mathbf{3}$ & KADANG & 4 & $8 \%$ \\
$\mathbf{4}$ & PERNAH & 0 & $0 \%$ \\
$\mathbf{5}$ & TIDAK PERNAH & 0 & $0 \%$ \\
& TOTAL & 50 & $100 \%$ \\
\hline
\end{tabular}


Berdasarkan data diatas dapat disimpulkan bahwa santri Pondok Pesantren Al-Firdaus tergolong memiliki kesopanan terhadap orang tua yang baik terbukti $56 \%$ selalu melakukan tugas sendiri, dan 0\% untuk yang pernah dan tidak pernah.

Tabel 11

Tingkat kesopanan kepada ustadz

\begin{tabular}{cccc}
\hline NO & ASPEK & JUMLAH & PERSENTASE \\
\hline $\mathbf{1}$ & SELALU & 25 & $50 \%$ \\
$\mathbf{2}$ & SERING & 20 & $40 \%$ \\
$\mathbf{3}$ & KADANG & 5 & $10 \%$ \\
$\mathbf{4}$ & PERNAH & 0 & $0 \%$ \\
$\mathbf{5}$ & TIDAK PERNAH & 0 & $0 \%$ \\
\hline & TOTAL & 50 & $100 \%$ \\
\hline
\end{tabular}

Berdasarkan data diatas dapat disimpulkan bahwa santri Pondok Pesantren Al-Firdaus tergolong memiliki kesopanan terhadap ustadz yang baik terbukti $50 \%$ selalu melakukan tugas sendiri, dan $0 \%$ untuk yang pernah dan tidak pernah.

Tabel 12

Tingkat kesopanan pada teman

\begin{tabular}{cccc}
\hline NO & ASPEK & JUMLAH & PERSENTASE \\
\hline $\mathbf{1}$ & SELALU & 12 & $24 \%$ \\
$\mathbf{2}$ & SERING & 18 & $36 \%$ \\
$\mathbf{3}$ & KADANG & 19 & $38 \%$ \\
$\mathbf{4}$ & PERNAH & 1 & $2 \%$ \\
$\mathbf{5}$ & TIDAK PERNAH & 0 & $0 \%$ \\
& TOTAL & 50 & $100 \%$ \\
\hline
\end{tabular}

Berdasarkan data diatas dapat disimpulkan bahwa santri Pondok Pesantren Al-Firdaus tergolong memiliki kesopanan terhadap teman yang baik terbukti $36 \%$ sering melakukan tugas sendiri, dan $0 \%$ untuk yang pernah dan tidak pernah.

Tabel 13

Tingkat kesopanan pada semua orang

\begin{tabular}{cccc}
\hline NO & ASPEK & JUMLAH & PERSENTASE \\
\hline $\mathbf{1}$ & SELALU & 11 & $22 \%$ \\
$\mathbf{2}$ & SERING & 25 & $50 \%$ \\
$\mathbf{3}$ & KADANG & 13 & $26 \%$ \\
$\mathbf{4}$ & PERNAH & 1 & $2 \%$ \\
$\mathbf{5}$ & TIDAK PERNAH & 0 & $0 \%$ \\
& TOTAL & 50 & $100 \%$ \\
\hline
\end{tabular}

Berdasarkan data diatas dapat disimpulkan bahwa santri Pondok Pesantren Al-Firdaus tergolong memiliki kesopanan terhadap semua orang yang baik terbukti $50 \%$ sering melakukan tugas sendiri, dan $0 \%$ untuk yang pernah dan tidak pernah. 
g. Kreativitas

Tabel 14

Tingkat Kreatifitas dalam keingin tau tentang hal baru

\begin{tabular}{cccc}
\hline NO & ASPEK & JUMLAH & PERSENTASE \\
\hline $\mathbf{1}$ & SELALU & 31 & $62 \%$ \\
$\mathbf{2}$ & SERING & 10 & $20 \%$ \\
$\mathbf{3}$ & KADANG & 8 & $16 \%$ \\
$\mathbf{4}$ & PERNAH & 1 & $2 \%$ \\
$\mathbf{5}$ & TIDAK PERNAH & 0 & $0 \%$ \\
& TOTAL & 50 & $100 \%$ \\
\hline
\end{tabular}

Berdasarkan data diatas dapat disimpulkan bahwa santri Pondok Pesantren Al-Firdaus tergolong memiliki tingkat kreatifitas dalam keingintauan tentang hal baru yang baik terbukti $62 \%$ selalu melakukan tugas sendiri, dan $0 \%$ untuk yang pernah dan tidak pernah.

h. Tanggung jawab

Tabel 15

Tingkat tanggung jawab dalam mengerjakan tugas dari pesantren

\begin{tabular}{cccc}
\hline NO & ASPEK & JUMLAH & PERSENTASE \\
\hline $\mathbf{1}$ & SELALU & 14 & $28 \%$ \\
$\mathbf{2}$ & SERING & 13 & $26 \%$ \\
$\mathbf{3}$ & KADANG & 22 & $44 \%$ \\
$\mathbf{4}$ & PERNAH & 1 & $2 \%$ \\
$\mathbf{5}$ & TIDAK PERNAH & 0 & $0 \%$ \\
\hline & TOTAL & 50 & $100 \%$ \\
\hline
\end{tabular}

Berdasarkan data diatas dapat disimpulkan bahwa santri Pondok Pesantren Al-Firdaus tergolong memiliki tingkat tanggung jawab dalam mengerjakan tugas dari pesantren yang baik terbukti 28\% selalu melakukan tugas sendiri, dan 0\% untuk yang pernah dan tidak pernah.

Berdasarkan data hasil lapangan mengenai karakter santri dapat disimpulkan bahwa $51 \%$ santri memiliki kejujuran yang sangat baik, 52\% santri memiliki tingkat kedisiplinan yang sangat tinggi, namun agak sedikit lebih rendah pada aspek kebersihan yaitu 48\% santri yang memperhatikan kebersihan dengan sangat baik, kepedulian santri dinilai masih sangat rendah yaitu hanya 18\% santri yang memiliki kepedulian tinggi. Kemandirian juga dinilai kurang tinggi yaitu hanya 32\% santri yang memiliki kemandirian dan kerja keras hanya 38\%. Namun memiliki kesopanan yang cukup baik yaitu $40 \%$, tanggung jawab $28 \%$, dan kreativitas $62 \%$. Berdasarkan data di atas, maka peneliti akan melanjutkan penelitian terkait dengan proses pembelajaran dan faktorfaktor yang menyebabkan tinggi rendahnya karakter santri.

\section{Upaya Pondok Pesantren}

Berdasarkan hasil wawancara terhadap 1 (satu) orang pengelola, 2 (dua) orang pengajar diperoleh hasil sebagai berikut yang disusun menurut indikator pertanyaan

a. Norma dan penguasaan pendidik dalam kegiatan belajar mengajar 
Menurut Pengelola, Sistem pembelajaran di Pondok Pesantren A-Firdaus dilaksanakan 24 jam karena seluruh aktivitas santri ada di pondok, sehingga apa yang diajarkana dalam pelajaran Adab yaitu berakhlakulkarimah bisa langsung dipantau oleh ustadz/pendidik. Hal ini sejalan dengan jawaban pengajar

b. Sertifikasi pendidik/ustadz belum ada, dilakuan kaderisasi untuk setiap angkatan yang sudah lulus diambil 4 orang ikhwan dan 4 orang akhwat untuk pengabdian untuk pengabdian dan mendapat beasiswa sampai perguruan tinggi dari yayasan.

c. Manajemen Pondok Pesantren dibawah Ormas Persatuan Islam Bidgar Pendidikan

Dalam pembentukan karakter santri yang menjadi upaya pondok pesantren adalah dalam mengelola pembelajaran dengan materi karakter yang lebih banyak yaitu $60 \%$. Pembelajaran akidah akhlak dan siroh (sejarah) yang menitik beratakan pada akhlakul karimah. Melalui penerapan ilmu secara langsung pada aktivitas sehari-hari di dalam pondok pesantren.

\section{B. Faktor Penghambat}

Di pondok pesantren para santri dibimbing dengan bimbingan akhlak yang terpuji dengan mempelajari siroh nabawiah (sejarah nabi) juga dari hadist-hadist. Namun ada juga hambatan misalnya dari perkembangan teknologi yang semakin deras, juga dari orang tua yang terkadang kurang totalitas mendukung atau masih memanjakan anakanaknya.

\section{DAFTAR PUSTAKA}

Ainiyah, N. (2013). Pembentukan Karakter melalui Pendidikan Agama Islam. Al-Ulum, $13(1), 27$.

Ali, M. D., \& Daud, H. (1995). Lembaga-Lembaga Islam di Indonesia. Jakarta: Grafindo Persada.

Dewi, F. A. (2015). Skripsi: Peranan Guru Dalam Managemen Interaksi Pembelajaran PAUD Melalui Kegiatan Bermain Peran Dalam Rangka Pengembangan Motorik Anak (Studi Kasus di PAUD Ar-Raudlah Kel. Sukasari Bandung). Bandung: STKIP Siliwangi.

Dhofier, Z. (1983). Tradisi Pesantren: Studi tentang Pandangan Hidup Kyai. Jakarta: LP3S.

Geertz, C. (1981). Abangan, Santri, dan Priyayi dalam Masyarakat jawa. Jakarta: Pustaka.

Kemendiknas, D. P. (2010). Kerangka Acuan Pendidikan. Jakarta.

Maksum, A. (2015). Model Pendidikan Toleransi di Pesantren Modern dan Salaf. Jurnal Pendidikan Agama Islam, 3(1), 85.

Mazzola, J. W. (2013). Bullying in School: a Strategic Solution. Washington, DC: Character Education Partnership.

Muhakamurrohman, A. (2014). Pesantren: Santri, Kyai, dan Tradisi. Ibda' Jurnal kebudayaan Islam, 12(2), 113. 
Syafe'i, I. (2017). Pondok Pesantren: Lembaga Pendidikan Pembentukan Karakter. AlTadzkiyyah, 8, 85.

Zulhimma. (2013). Dinamika Perkembangan Pondok Pesantren di Indonesia. Darul 'Ilmi, 1(2), 165. 